\title{
E-Service Delivery in Bangladesh: Major Challenges and Plausible Propositions
}

\author{
Mohammad Abdul Salam \\ Senior Assistant Secretary \\ Ministry of Public Administration \\ Bangladesh Secretariat, Dhaka
}

\author{
Md. Zohurul Islam \\ Assistant Professor \\ Institute of Governance Studies \\ BRAC University, Dhaka
}

\begin{abstract}
E-governance is essential to craft a transparent and effective government service, to increase government efficiency and accountability and to improve the service delivery. The present government took the initiative to implement e-governance through their election manifesto but the implementation of egovernance in Bangladesh is not satisfactory because of good number of grounds. The current study is focused on some constraints of e-governance after surveying in some selected districts of Bangladesh and provided some possible suggestions to conquer those predicaments for achieving the Digital Bangladesh. The study results revealed that lack of skilled manpower is the major challenge of e-service delivery while arranging proper computer and IT training is the foremost important tool to overcome the implementation of e-service delivery route in Bangladesh
\end{abstract}

\section{General Terms}

DESC (District E-Service Centres), UISC (Union Information \& Service Centres), ICT (Information and Communication Technology), IT (Internet Technology)

\section{Keywords}

E-Governance, e-Service, Challenges, Propositions

\section{INTRODUCTION}

A new dimension to the governance arena has added with the advancement of Information and Communication Technology (ICT) and the concept of e-governance have emerged. It is widely accepted as effective tools of service delivery. Advancement in Internet Technology (IT) is creating new aspirations and expectations among people for enhanced and quality service delivery. Public service delivery is the main rationale for the existence of any popularly elected government. Thus, every government takes various initiatives to bring about changes within their existing traditional and process-oriented administrative systems and to achieve the trust and seek support from its citizens in the course of delivering public services efficiently.

Before the e-governance era, the public services had delivered through the conventional way where connecting citizens were hardly concern and doorsteps services were totally ignored. Thus, the government of Bangladesh has set-up e-service centers at Union (UISC), Upazila and District (DESC) level as part of e-governance scheme to provide the services at the doorsteps of citizens and connecting the people of countryside. E-service delivery is very different from traditional service delivery. Ghosh et al. (2004) conceptualizes e-service as interactive information service among the service providers, service recipients and agencies. Electronic service (e-service) is becoming increasingly important in providing customers with a convenient service with interactive information flow in the transaction process (Santos, 2003). But shortage of power, lack of skilled manpower and existence of bureaucratic style has challenged to change to deliver the public services efficiently. Therefore, the e-service centres are incapable of creating close coordination between the various government agencies or business groups or citizens for achieving the desired objectives. Thus creating a gap and between government and its main stakeholders or citizens. This gap is gradually becoming wider and citizens lose their trust on government. In this context, it is an urgent need to minimize the gaps.

The core intention of e-governance is to allow the public sector to provide citizens with information based on their need. Along the lines of the connotation, the research has focused on the involvement of e-government tools in enhancing the efficiency of public organizations and its implication among citizens through e-service delivery. This study is tried to assess the major challenges and plausible propositions of already set-up the e-service centres.

\section{METHODOLOGY}

Bangladesh has made a significant development in all indicators of e-readiness index (Islam and Khair, 2012) in spite of some difficulties has faced to implement the e-governance initiatives by the government of Bangladesh. In this research, out of 64 DESC of Bangladesh four service centres has selected to study named as Mymensingh, Shariatpur, Madaripur and Dhaka district as category A, B, C and special category respectively which represents all others service centres. The challenges and propositions for e-governance study were done by the informal interviews of government officials and staffs those worked in District E-Service Centres. Two questions were asked with in quest of two more answers for each.

\section{RESEARCH FINDINGS}

\subsection{Major challenges}

The study attempted to know the challenges of e-governance in Bangladesh through the interviewing of service providers. The service providers were government officials and staffs worked in DESC. The research was conducted total 32 service providers under the interviewing of the study. The stature illustrated (see Figure 1) a huge number of challenges of egovernance in Bangladesh where lack of skilled manpower $(15.63 \%)$, shortage of power supply $(12.50 \%)$, lack of awareness $(10.94 \%)$ and unwillingness of service providers $(9.38 \%)$ claimed as key disputes. Moreover, slow connectivity of internet, shortage of Internet Technology equipment and lack of information are also asserted as e-governance challenges in Bangladesh. 


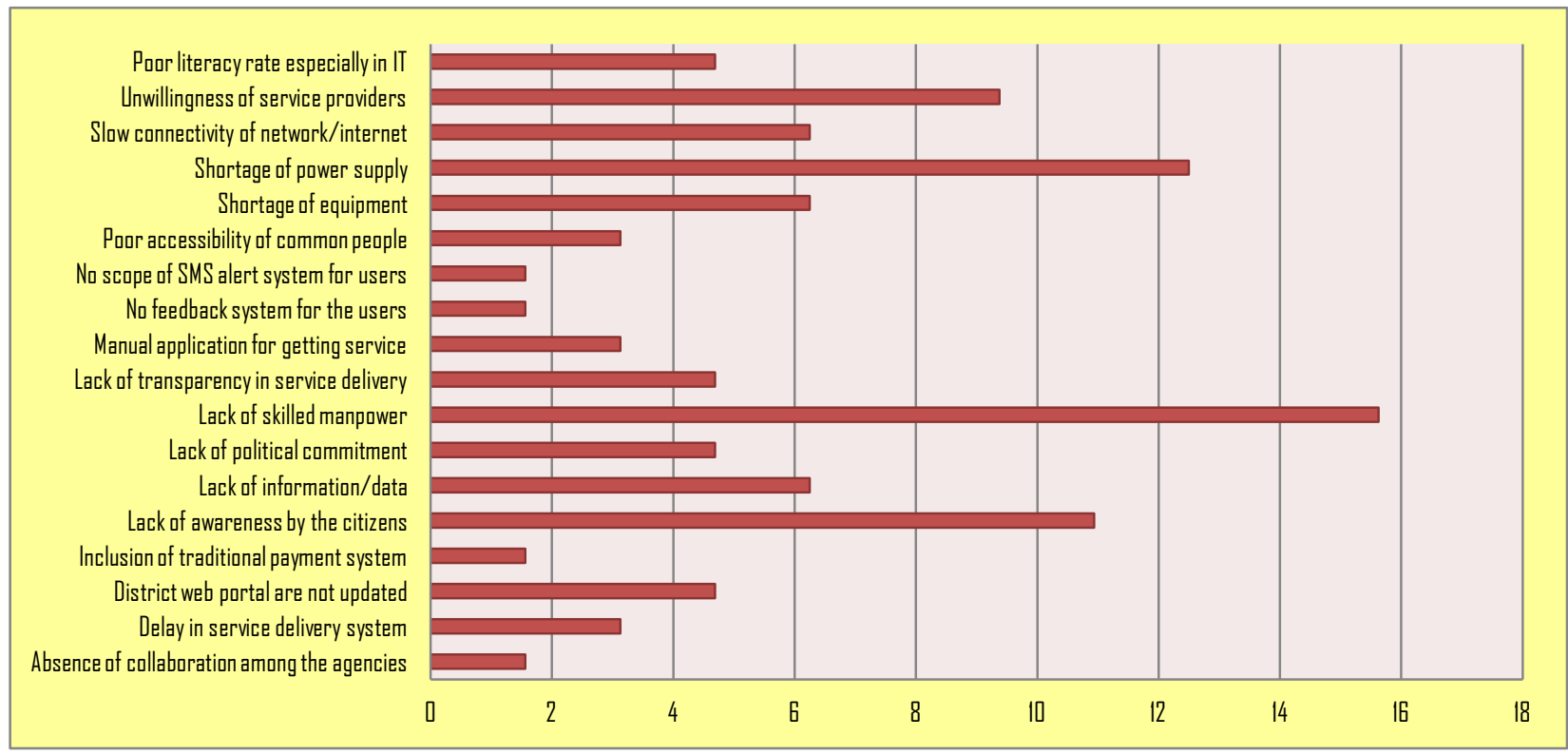

Figure 1. Challenges of electronic governance in Bangladesh (in percentage)

\subsection{Plausible Propositions}

Besides the challenges of e-governance, the study also scrutinized some propositions from the interviewers who were pub officials and staffs played their roles as service providers. The research was conducted total 32 service providers under the interviewing in order to find out the propositions for efficient egovernance. The standing illustrated (see Figure 2) a good number of suggestions for efficient e-governance in Bangladesh. The study summarized a number of propositions like arrange proper computer and IT training (15.63\%), buildup awareness program (14.06\%), supply sufficient amount of power $(10.94 \%)$ and need political commitment and mindset of service providers $(9.38 \%)$. In addition, supply of sufficient of IT equipments, manage high speed of internet connectivity and web portal bring up to date are some important scheme to egovernance initiative.

\section{DISCUSSIONS}

The subsequently discussion highlights the findings from the qualitative results of informal interviews. Knott and Dawson (1999) identified three reasons for poor project planning in ICT sectors like risk management had not been addressed, business system had not been justified and lack of involvement from management. Khaled (2003), Gakhunu (2004) and Ndou (2004) tried to find out the factors of ICT project implementation failure. Some of these are infrastructure, finance, skilled personnel, attitudes, cultures and leadership styles, Jaeger (2003) described several broad areas of e-government obstacles like security, privacy, homeland security, digital divide, economic disparities, education, accessibility, prioritization, citizen awareness and confidence. Baptista (2005) found that conflicting policy elements within the agenda magnify the need for more public debate on the desired outcomes of egovernment.

\section{Supply sufficient amount of solar/electricity Supply sufficient amount of equipments Strong collaboration among the agencies Introducing intraduce SMS alert system Intraducing feedback system Online payment system Need political cammitment and mindset Need online application facility Mativation program for service provider Manage high speed of connectivity Maintain database in service delivery Expansion and continuation of services District web portal should be updated reqularly Build-up awareness program Available information/data for people Assurance of transparency in service delivery Arrange proper computer and IT training}

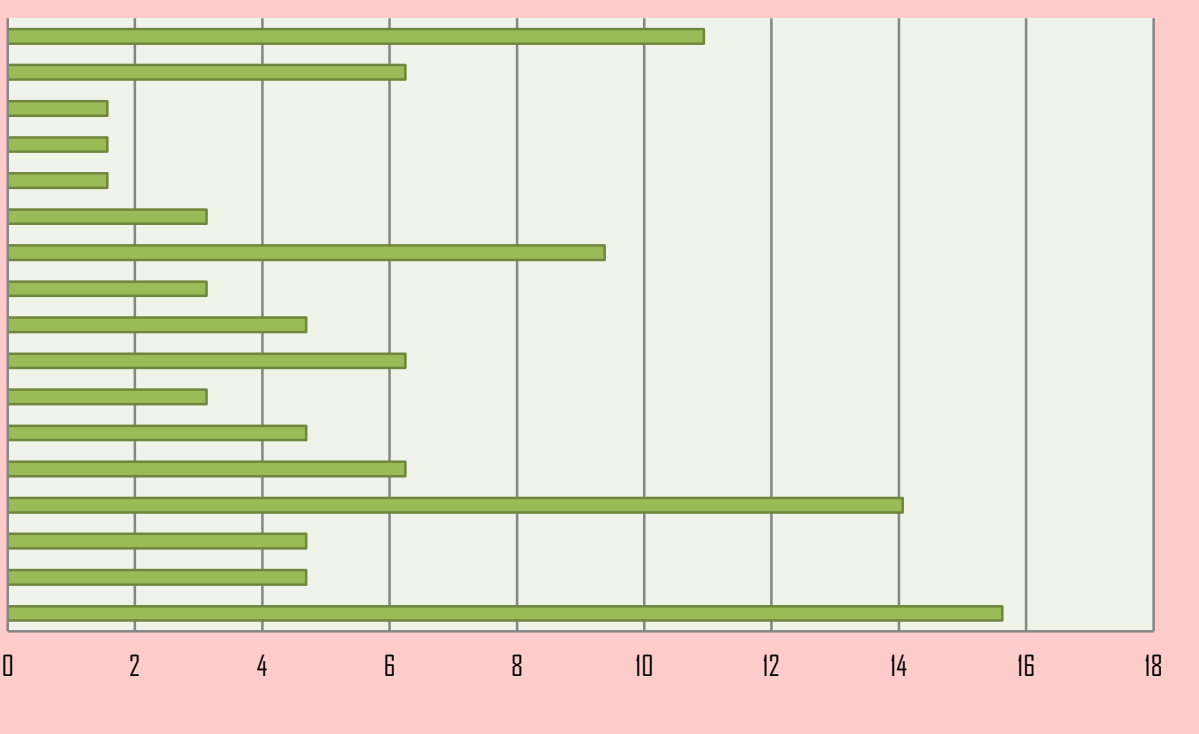

Figure 2. Propositions for Electronic Governance in Bangladesh (in percentage) 
He also mentioned that the citizens have limited awareness both the potential benefits and its associated risks. Srivastava and Sharma (2010) identified geographical, social and economical disparities among citizens were the biggest barriers for egovernance. Illiteracy, lack of infrastructure, security and privacy of personal and financial data were other constraints that hamper e-governance efforts. Bwalya (2009) faced some challenges on e-government like low level of internet penetration, lack of budget, lack of citizen awareness, limited IT skill and training etc. Hossan et al. (n.d.) stated, the most critical factors contribute to the failure of e-government implementation in Bangladesh are lack of internal political desire, inadequate technological infrastructure, lack of overall vision or strategy and dominance of politics or self interest. The present study stanched that the lack of skilled manpower, shortage of power supply, lack of awareness, unwillingness of service providers were found as challenges of e-governance service delivery which justified by the previous research findings.

Gronlund et al. (2005) pointed out that for e-government projects to be effective, focus must be placed on social and economic context. Asgarkhani (2005) claimed the lack of access to ICT and insufficient technology for enabling e-service is causes of ineffectiveness on which the success of e-service initiatives depends on. Athmay (2012) also pointed some driving forces for e-governance improvement like trends on online business, internet facility, and better service delivery and so on. Clockwork (2004) suggested a framework for implementing e-government projects which consists five stages like examine e-readiness, identify and prioritize themes, develop a program, apply to target groups and implement solutions. According to Hossan, et al. (n.d.), the most important factors for successful implementation of e-government in Bangladesh are internal political desire, technological infrastructure, overall vision or strategy, change management and competencies among the officials. The current research pointed out that ICT training, awareness build-up among the citizens, sufficient power supply and also political commitment must need to proper implementation of the e-service delivery schema.
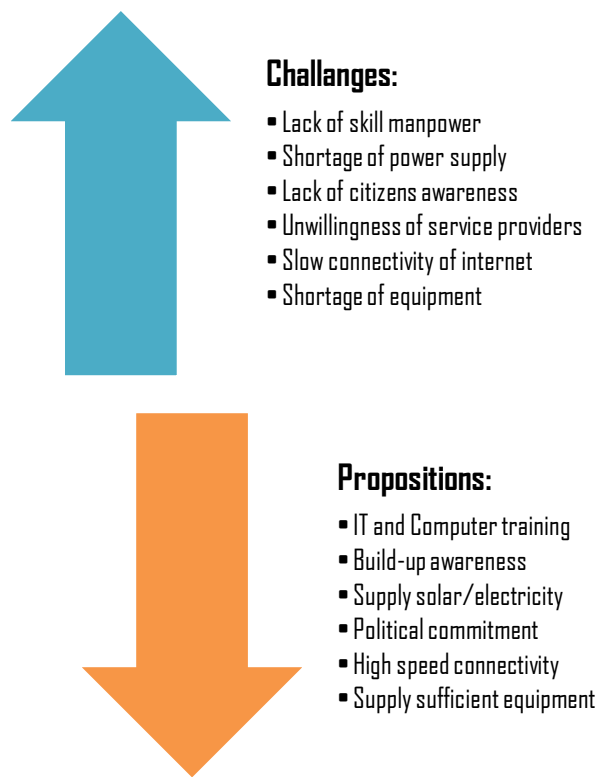

Figure 3. Proposed diagram of e-governance implementation (modified by Athmay, 2012)

\section{CONCLUSIONS}

E-governance is the use of modern information and communication technologies such as internet, local area network, wide area network, mobiles, etc., by government to improve effectiveness, efficiency, and service delivery to citizens and promote transparency (Bretschneider et al., 2003). The proposed model (see Figure 3) has drawn on the basis of service provider perception about the e-governance. It includes the challenges and propositions to proper e-government implementation in Bangladesh.

The present condition of good governance in Bangladesh is not satisfactory particularly to service delivery. Proper implementation of e-government tools may have the positive role to ensure good governance in public service delivery.

a. A central body must be institutionalized that can coordinate with ministries and execute the necessary reforms to make achievement of the citizen-centric pillars of e-governance. Thus, the negligence and the failure of the e-governance initiatives can be monitored.

b. Strengthen the regulatory framework by amendment of the ICT Act 2009 with inclusion of adequate data privacy and security provisions and the RTI Act 2009 must be put into action so that citizens can have access to information quickly and effectively.

c. Awareness raising and competitive pricing are essential as people need to see a value to these centres in order to use them. Here, electronic and print media can play their roles.

d. Ensure business process-engineering and adequate ICT infrastructure allowing automation to make processes faster and more efficient for citizens. Institutional restructuring, reforms and capacity building also required to provide government services.

e. Establish adequate data privacy and security provisions that ensure the confidentiality of sensitive personal information and prevent unauthorized access to it. In addition, the volume of the e-service must be increased for the citizens.

f. Government e-services are particularly important in rural areas, and the failure to roll out a platform for egovernment in rural areas has been identified as a major obstacle to attaining government e-services in the developing world like Bangladesh.

At last, it is an imperative need for a comprehensive legal framework for realization of e-governance. There needs to be a well-planned program to create a greater number of IT human resource in the country. IT literacy programs should start early in schools, the local software companies should take steps to become more prepared for handling government IT projects, steps need to be taken to explore alternative sources of power or alternative means of power generation.

The research study has certain limitations that could provide opportunities for further research. The methodology could look to expand by conducting focus groups involving citizen users, apart from administrators and IT managers. However, the views of service receivers could be amass in further study.

\section{ACKNOWLEDGMENTS}

Our thanks to the authority of Institute of Governance Studies, 
BRAC University for overall support for academic and research work. We wish to express our deep gratitude and sincere appreciation to Dr. Rizwan Khair, Director, Institute of Governance Studies, BRAC University, Bangladesh. We are also acknowledge the inspiration from Dr Shah Mohammad Sanaul Hoque, Deputy Secretary, Prime Minister's Office, Government of the People's Republic of Bangladesh.

\section{REFERENCES}

[1] Asgarkhani, M. 2005. The Effectiveness of e-Service in Local Government: A Case Study, Electronic Journal of eGovernment, 3(4): 157-166

[2] Athmay, A.A. 2012. Assessing the implementation of egovernance in Arab countries, International Journal of Information Technology and Business management, 5(1): $20-40$.

[3] Baptista, M. 2005. E-Government and State Reforms: Policy Dilemmas of Europe, Electronic Journal of $e$ Government, 3(4): 167-174.

[4] Bretschneider, S., Gant, J., and Ahn, M. 2003. A general model of e-government service adoption: empirical exploration. Public Management Research Conference, Georgetown Public Policy Institute: Washington D.C.

[5] Bwalya, K.J. 2009. Factors Affecting Adoption of eGovernment in Zambia. Electronic Journal of Information Systems in Developing Countries, 38(4):1-13.

[6] Clockwork, 2004. A framework of e-governance and ICT best practices, Internation Institute for Communication and Development [Available at http://www.iicd.org/about]

[7] Gakuno, P. 2004. E-Government Strategy for Kenya [Available at: http://www.apc.org/apps/img_upload]

[8] Ghosh, S., Surjadjaja, H., and Antony, J. (2004). Optimization of the determinants of eservice operation
Business Process Management Journal, 10(6): 616-636.

[9] Gronlund, A., Andersson, A. and Hedstrom, K. (2005) Next step e-government in developing countries. Informatics Department, Orebro University, Sweden.

[10] Hossan, C.G., Habib, M.W. and Kushchu, P.I. (n.d.). Success and failure factors for e-government projects implementation in developing countries: a study on the perception of government officials of Bangladesh.

[11] Islam, M.Z. and Khair, R. 2012. Preparation of egovernment in Bangladesh: An explanatory analysis. $J U$ Journal of International Technology, 1: 19-26.

[12] Jaeger, P.T. 2003. The endless wire: e-government as global phenomenon. Government Information Quarterly, 20(4): 323-331.

[13] Khaled, M. 2003. Information technology in government: an action plan for Bangladesh [Available at: http://www.sictgov.org/IT\%20/Action\%20/Plan\%20]

[14] Knott, R.P. and Dawson, R.J., 1999. Software project management. Loughborough: Group D Publications.

[15] Ndou, V., 2004. E-Government for developing countries: Opportunities and challenges. [Available at: http://www.is.cityu.edu.hk/research]

[16] Santos, J. 2003. E-service quality: A model of virtual service quality dimensions. Management Service Quality, 13(3): 233-246.

[17] Srivastava, D. and Sharma, B.K. 2010. Preparing citizens as active participators in e-governance: the making of ecitizens. International Journal of Engineering Science and Technology, 2(9): 4651-4654. 